\title{
Musical Aspects for Empowering the Black Characters in the Movie Get Out (2017)
}

\author{
Syeikha Annisa Marasabessy and Lucia Lusi Ani Handayani ${ }^{1}$ \\ English Study Program, Faculty of Humanities, Universitas Indonesia
}

\begin{abstract}
In the 21 st century, the representation of Black people in many U.S. movies is still problematic, for the movies do not omit the stereotypical representations of Black people, which are often depicted being disrespectful and unintelligent compared to other races. Many movies have been trying to change them into another perspective, yet they are still unable to get rid of those stereotypes completely. By looking through the cinematic aspects, the dialogues, and the symbols along with the sounds and music used, this paper examines the stereotypes of Black characters in the movie Get Out (2017) by Jordan Peele using discourse analysis. The paper observes that the representation of the movie still distinguishes Black from White in the aspects of the body over mind in Black masculinity, incivility, and distinctive racial labour. As a result, Black characters are seen inferior compared to White characters despite the movie's effort to empower them. The use of music also emphasizes the power relation difference between the two races. The overall finding of the paper reveals that the existence of Black stereotypical depiction is still found in a movie empowering Black people, and it shows that race representation should be monitored thoroughly.
\end{abstract}

Keywords: musical aspects; representation; stereotypes; characterizations; Black people

\begin{abstract}
ABSTRAK
Aspek Musikal untuk Memberdayakan Karakter Kulit Hitam di Film Get Out (2017). Pada abad ke-21 ini, representasi orang kulit hitam di banyak film Amerika problematis karena film-film tersebut tidak menghilangkan representasi stereotip orang kulit hitam yang mana sering digambarkan tidak sopan dan kurang cerdas dibandingkan dengan ras lain. Banyak film sudah mencoba mengubah stereotip tersebut ke perspektif lain, namun film-film tersebut masih belum dapat sepenuhnya menghapuskan stereotip yang ada. Dengan melihat aspek sinematik, dialog, simbol, suara, dan musik yang digunakan, artikel ini menganalisis stereotip karakter orang kulit hitam dalam film Get Out (2017) oleh Jordan Peele menggunakan analisis wacana. Artikel ini menemukan bahwa keseluruhan representasi dalam film tersebut masih memisahkan kulit hitam dari kulit putih dengan lebih mengutamakan aspek tubuh daripada pikiran dalam maskulinitas kulit hitam, sikap yang tidak sopan, dan perbedaan jenis pekerjaan. Sebagai hasilnya, karakter kulit hitam terlihat inferior dibandingkan karakter kulit putih meskipun film ini berusaha untuk memberdayakan orang kulit hitam. Penggunaan musik juga menekankan adanya perbedaan kekuasaan antara kedua ras. Keseluruhan hasil analisis dari artikel menemukan bahwa penggambaran stereotip orang kulit hitam masih terlihat dalam film yang memberdayakan orang kulit hitam. Hal ini menunjukkan bahwa representasi ras menuntut pengamatan secara mendalam.
\end{abstract}

Kata kunci: aspek musikal; representasi; stereotip; karakterisasi; orang kulit hitam

\section{Introduction}

"You ever get into street fights as a kid?" asked a White character towards a Black character in the movie Get Out (2017) as the first impression of meeting him. The Black character has not even done anything on the previous scenes. This kind of question is familiar to be asked towards Black people even outside the movie. It is influenced by the stereotypes in the U.S. society about Black

Correspondence: English Study Program, Faculty of Humanities, Universitas Indonesia. Jln. Margonda Raya, Depok 16424, Phone: 082118041203 E-mail: syeikhaannisam@gmail.com \& lucia.lusi@ui.ac.id. 
people. There are also many other stereotypical questions and statements uttered by other races towards Black people. Due to that fact, it is worrisome that Black people are still seen negatively in the U.S. society. Not only does it influence other people's view on them, but it also affects their mindsets. As a result, Black people become insecure about their surroundings because of the stereotype sticking to their race.

The idea itself can be created through popular culture. Popular cultures, like movies, have been known as one of the most influential mediums to spread views or beliefs. Movies, nowadays, have been trying to empower certain races, such as the Black race, even though there have been many movies in the past which degrade certain races. However, despite their effort on the notion of empowerment, some negative stereotypes are still glued to the Black characters. By borrowing the term explanation by Lathan (2016), empowerment means persons or a group of individuals obtaining the power to act in creating a positive change in their lives or community "when given the resources and opportunity" (p.16). That is, they try to improve their lives in society. It brings the term 'Black empowerment' into account which, according to Kavari (2018), is equal to freedom or to empower Black people. He has also stated that it aims to get Black people having equal opportunity as Whites, their historical opposition. It can be said that stereotyping Black Americans in movies according to those constructed in the U.S. society has been the main issue in the discourse of movies related to Black Americans. That is, some movies claiming the attempt to deconstruct label about races, particularly Black people, have problematic representations that still restrain some, if not all, stereotypical depictions of Black people that have been circulated in the society.

Previous studies have also analyzed some cases related to problematic representations of Black people based on stereotypes in movies. They are usually portrayed in comparison to their historical opposition which is White people. In the physical aspect, Black people are known for their athletic prowess, so they have their own term for that, Black masculinity. However, Griffin \& Calafell (2017) and Trujillo (1991) (as cited in Adams (2015)) have found that Black men's masculinity is not even close to being portrayed as graceful as White men's masculinity. This finding shows that the trait is depicted negatively. In order to add the negative stereotypes to Black people, Ştefanovici (2014) analyzed the movie "Akeelah and the Bee" (2006) and found that the Black characters are depicted to have less intelligence than White people. The representation degrades Black people's intellectuals. Not only that, but Black people are also depicted as gangsters or being unemployed (Tyree, Byerly, and Hamilton (2011) as cited in Adams (2015)). Their behaviours and jobs are perceived to be negative.

Due to all those reasons, this paper examines the representations of Black characters in a popular movie directed by Jordan Peele titled Get Out (2017). The story narrates around a strange incident happening to a Black man named Chris Washington. His life with his White girlfriend, Rose Armitage, goes smoothly until he is invited to the isolated house of her family, the Armitages. The family consists of Dean Armitage, Missy Armitage, Rose Armitage, and Jeremy Armitage. At first, Chris feels comfortable, but he becomes surprised to see two fellow Black people working as servants in the Armitages' house. Moreover, they act strangely. Not long after, he experiences the horror of being a part of the Black race in a house full of the White people as he sees another Black man who comes as a guest named Logan King who acts very weird. Finally, he finds out that her girlfriend's family's job is to sell Black people's bodies through an auction. As Chris cannot be contacted in the house, his best friend Rod, a fellow Black person, tries to rescue him once he is aware of the dangerous situation Chris is facing. It turns out that his body is going to be taken by a White person who needs his body through an auction. In short, this movie represents two races, Black and White, and those characters have various jobs and characteristics. Also, the movie puts Black characters as protagonists while White characters as antagonists.

Being an Oscar-winning movie, several analyses have been conducted by some researchers about this movie from different perspectives. Based on its genre, there is humour in the movie given 
by the main character's best friend, but most parts are about its creepiness (Hazelton, 2017). Hazelton has also thought that there is a social comment on the movie of the way black man gets scared in the houses of middle-class people. Landsberg (2018), who has analyzed the movie from a cultural approach, has found that the movie uses genre horror to open the issue of racism. In the view of an educational perspective, Henry (2017) has noticed that the movie challenges the people in education to think thoroughly about black people's future because of the issue of anti-blackness and White supremacy. Other findings have examined that the movie flatters Black people through the dialogue with White people, such as black man's athletic prowess and his body (Landsberg, 2018) and his physical ability and good eyes (Williams, 2017). To sum up, many studies that have been done on the movie have discussed the power relation between White and Black people and stereotypical glorification towards Black people in the movie.

The movie seems to empower Black characters with its plot, yet if we look deeper, there are problematic characterizations in them, which have not been discussed. That is, it seems that the movie's portrayal of Black characters is still aligned with the stereotypes of Black people despite its objective to remove them. By that, this study will further analyze the depictions of Black characters in the movie and how they affirm to the stereotypes of Black people in the U.S. society through discourse analysis. At the end of this paper, it is expected to enhance people's understanding of how a movie needs to be dug deeper and seen from many perspectives to be understood clearly. From many perspectives, a movie can have many meanings. It is also important to note that popular cultures are capable of forming and shaping a full image of a race through representations.

\section{Chris Washington and Logan King: 'Body Over Mind'}

One of the most heard stereotypes of Black people is about Black masculinity, and one aspect of Black masculinity is the emphasis on their physical characteristics. The movie illustrates two Black male characters, Chris Washington and Logan King, which matter more through physical rather than intellectual traits. It is seen in their portrayals, and several symbols through several scenes in the movie Get Out (2017). According to Collins (2004), Black male bodies generate admiration through three aspects, which include physical strength, aggressiveness, and sexuality. Besides, their bodies are 'the boundary between admiration and fear' (p.153). Therefore, this paper is going to discuss the depiction of Black masculinity in certain scenes of the movie Get Out (2017), one of which is linked to admiration, fear, or the combination of both.

Before anything, Black masculinity is known to be feared. Chris provokes fear when he displays his physical strength and aggressiveness. It is seen from the way he rescues himself right before the surgery happens (01:28:17). Using only one hand with two strikes on the back of the head, he can make Jeremy's head full of blood. Not only that, but he also kills Dean all at once (01:29:22). He kills him using the head of a deer imitation. The deer image always shows up every time he faces an awkward situation so that the deer can be interpreted as endurance (Fletcher, 2013). That is, it depicts the endurance that Chris goes through. Then Georgina, whose body is already taken over by Rose's grandmother, looks scared and runs away after she sees that Chris is still alive (01:30:05 01:30:11). As desperate as he is, Chris uses his strength to fight those people back right before he is taken to the operation room. This outcome of energy comes from him as a self-defence mechanism. The whole family becomes a mess as Chris is trying to get out. Chris' Black masculinity aspect here is related to Collins (2004) who has argued that wildness is associated with Black people as a race, and they are seen as out of control (p.56). The fact that he can take down many people at once shows that his physical strength and aggressiveness in the stereotypical Black masculinity.

In comparison, Logan's change in physical behaviour expresses White people's boundary between admiration and fear. The portrayal of 'body over mind' in Logan's character is seen through the reactions from White people. When Logan is talking to Chris and some White people, Chris 
takes a photo of him but unintentionally uses flash. Logan, whose real soul wakes up, shouts at Chris and screams "Get Out!" (00:55:46). White people are seen startled when they see Logan getting so worked up towards Chris. Reacting to Logan, some White people look scared, but a White woman in red (00:55:53) seems to laugh as Logan approaches Chris. It is caused by the fact that she is already aware of the reason, so when they look scared at first, the scene looks confusing as a woman does not. It depicts the White irony characters feel about it, between fear and admiration, since they already control the soul that wakes up. Not long after, Jeremy Armitage restrains Logan, and Chris looks scared and surprised (00:56:00 - 00:56:06). Instead of telling Logan to calm down, Jeremy restrains Logan's body as if Logan is ready to attack Chris. This particular image, even though probably not intended, affirms to the stereotype of Black masculinity which states that Black people are inclined to violence and driven by instinct' (Collins, 2004). Jeremy restraining Logan symbolizes 'taming' Black people's masculinity. Thus, aggressiveness aspect is seen in Logan's reaction towards Chris.

Changing from fear to admiration, this movie uses the changing soul and hypnosis as the medium which symbolizes 'taming' Black people. As long as White people can possess Black people's body, it turns into admiration. From wild to tamed, Logan's character seems to matter more on the outside rather than the inside. Logan's athletic body is seemingly more important than his soul. As he was 'calmed down' by Missy Armitage, his soul goes and changes into a White American's soul (00:56:26). The situation becomes all right for White people but not 'all right' to Black people. Collins (2004) has also added that admiration comes if Black people have been 'tamed' by White people. As Logan has been 'tamed' by Missy Armitage, he seems to be Whiter. He has been put under White people's control, so his Black masculinity trait becomes admired by White people.

Admiration of Black masculinity in Chris' character is seen through his character's portrayal. When Chris is shirtless while shaving in front of a mirror, he is depicted as a Black man with big body muscles (Get Out, 00:05:31). Having a strongbuilt body signifies the Black masculine look. The ambience is added by the calm and relaxing music. Being shirtless and the addition of music contributed to the sexualized atmosphere. As stated by Collins (2004), athletic body is related to Black masculinity which in a way that Black male bodies evoke admiration (p.153). By having an athletic body, the depiction of Chris raises admiration. Not only is physical strength shown through this scene, but sexuality is also expressed. In short, there are two aspects of admiration shown when Chris is shaving.

Another admiration scene which depicts Black masculinity in the movie is the garden party scene. Chris' physical strength is highlighted through a conversation, and it leads to the correlation between Black men's body and sport. In a scene, Gordon Greene, a White man, says to Chris "You, uh, ever played golf?" (00:42:43). The association of a Black man and sport, or being athletic, is depicted through the question. Asking about whether Chris plays a sport or not seems to be normal for Gordon as it is the first thing he says towards Chris. Black men are always associated with sports, and they should be able to do at least one sport. Even if, in reality, he cannot do sports, Chris is expected to have a good figure by Gordon adding to what he has said, "So, Chris, let's see your form." (00:43:09). The use of the word 'form' emphasizes that the topic brought by a White man towards a Black man focuses more towards the physical appearance instead of interests. As Chris' Black masculinity trait is going to be owned by one of the White people there, they admire his body as if it is an object to be bought. It becomes admired by White people only when it is going to be owned or put under control by White people.

\section{Lacking Civility}

Aside from depicting Black masculinity which emphasizes on the body over mind, Black characters are also depicted lacking civility, especially compared to White characters. It is seen through their use of profanity and racist remarks when they are talking. That is, they do 
not filter their words when they utter something. It is related to the concept of civility, which Boyd (2006) (as cited in Clark (2008)) has stated that to be responsible citizens, some groups of people such as immigrants, ethnic minorities, and the poor have to be civilized. He has also added that the concept of civility itself has a negative connotation to a certain extent, and from the previous statement, it means that it only applies towards minorities. The movie also puts scenes which include Black characters using profanity and racist remarks which are covered as jokes between Black people, so this aspect becomes one of the problematic aspects of the movie.

As the first notable scene of profanity, Rod's character is depicted as a person who easily curses and swears on a thing or a person. He seems familiar to profanity because of the high intensity of using it. On a scene, Rod tells Chris about his experience as a TSA agent while joking about an old lady hijacking a plane by uttering "how can I get in trouble for patting down an old lady?" (00:09:09 - 00:09:13) Furthermore, "Gary just think 'cause an elderly bitch is elderly, she can't hijack no motherfucking plane." (00:09:14 00:09:18). The expression he uses to refer to her is 'elderly bitch' which has a negative connotation. The use of swear word 'bitch' after the word 'elderly' shows irony in the way the character is portrayed. The word 'elderly' and 'old' shows politeness, while the addition of the word 'bitch' makes the sentence ironic. Not only that word but also other words such as 'motherfucking' is uttered by him showing that he is familiar with those words. Rod also adds, "I'm a serious man. The next $9 / 11$ is gonna be on some geriatric shit." (00:09:20 - 00:09:23). In this sentence, he adds the word 'shit' in the end. As he adds a swear word in each utterance, it shows that he has the habit of including it in his sentences. Thus, it affirms to the stereotype of Black people saying curse words which act as a hint of being primitive.

In another scene, Rod brings the profanity to the level of sexual harassment. Right after Chris tells Rod about his plan of going to Rose's house, Rod replies by saying, "like don't go to a White girl's parents' house. What's she doing? Licking your balls or something?" (00:10:00 - 00:10:05). After responding briefly to Rod, Chris hangs up the phone as soon as he hears Rod's response. Chris looks uncomfortable while hearing Rod's statement in the conversation. It is because Rod is making an inappropriate comment towards Rose. He assumes that coming to Rose's parents' house is only connected to sexuality. Also, Rose is mentioned as a 'White girl' highlighting to Chris about the fact that they belong to different races. In a way, Rod focuses on the negativity that might happen in a White family's house in general because they have a negative historical memory with the counter race. The problematic part of this statement is that the way he warns Chris is a degradation towards Rose.

Being aware of his inappropriate comment in a formal setting, Rod apologizes towards the police officer. He also emphasizes by saying, "brainwashing them, making them work for them as sex slaves and shit" (01:17:29). Saying the word 'shit' in a place he should not do so, and he knows that he did wrong, so he says, "sorry for the 'shit". There comes his realization of problematic language use when he counters a situation that he needs to face the police officers. He knows that he should be more 'civilized', so he tries to talk in a better manner than his usual self. However, after the plot goes further towards the police officers and how they think, the movie depicts the police officers also having problematic attitudes. The police officers, all of whom are Black characters, are seen as if they try to joke around even in a serious situation like a missing report. This plot twist makes the Black characters seem to be the people who like to joke around and lacks thinking. They are portrayed as not having 'attitude' or 'ethics' that are learned from White characters in the way of 'Civilization'. Rod also uses slangs a lot which Weaver (2016) refers to the portrayal of Black people not being able to speak grammatically correct English as a hint of a lack of intelligence.

Not only does Rod have racist remarks, but the police officers have also done similar things. In this case, a Black female police officer who gets a report from Rod also degrades White women. After she finishes listening to Rod's story, she calls other officers to listen too. However, their response 
is not severe, and they make a joke out of it. On top of that, she even adds racist remarks about White women by saying, "Oh White Girls! Oh, they get you every time" says a Black female police officer $(01: 18: 44)$. As she talks about how White women get Black men every time, it creates an image of how White women, Black men, and their relationship are perceived within Black society. That is, there is a stereotype that Black men are easily attracted to White women. (Malebranche, 1997 (as cited in Weaver (2016)). The conversation depicts Black people like people who joke in a difficult situation. It is not polite towards someone who comes for filing a report.

As the police officers are wearing their formal clothing, they are seen as civilized people, and they are expected to give professional, logical reasoning for anyone who files a report without judging through their races and background. By wearing it, they need to have a good attitude and ethics to the public. However, the characteristics shown by these Black police officers towards another Black person trying to file a report are considered unprofessional. "Oh, White Girls! Oh, they get you every time" says a Black female police officer (01:18:44). Through this conversation, they include their perspective on races. The scene gets complicated because the officers' outer look shows that they are being civilized, yet their inner personalities and attitude affirm to the stereotype of Black people being uncivilized.

\section{Labor Division between Black and White Characters: Physicality vs. Intellectuality}

As a connection from Black masculinity and civility which are depicted in previous sections, this part mainly focuses on the division of labour in Black and White characters as they are the only races represented in the movie. The findings from other parts are mainly about the way Black characters are seen more for outer traits rather than inner and the problematic manners they have in the movie. In this part, the division of job belonging to Black characters is studied through Chris Washington, Rod, Logan King, and Black police officers, while for the White people, it is studied through the
Armitages and Jim Hudson. According to Schlereth (1991), traditional hand-labour is done by Black people, while the White people use advanced technology. In the movie, there is, indeed, a clear labour division between Black and White people according to the stereotype. This study found that Black characters' jobs in this movie are depicted to have a tendency towards physicality more than intellectuality, which is different from White characters who seem to possess intellectuality.

Black characters in the movie have different kinds of jobs, such as police, TSA agent, photographer, and singer, which are categorized to Black people's circle of occupations. The first case is regarding Rod and other police officers who have the occupations related to their physical ability. It is already known that being an agent or a police officer requires someone to be athletic. Rod, as a TSA agent, wears a blue uniform which shows his capacity and expresses power in his workplace, and the police officers wear their uniforms. However, by doing so, their actions are limited to the official rule and behaviour set by the official. According to Hertz (2007), there is a high level of hierarchical control to people who wear uniforms (p.44). Uniform restricts the movements of the people, usually employees, as they are not in a high position. Even though some Black characters have power, they are restricted to the regulations.

Another case of Black characters' job is more to the freelancer like Chris and Logan King. Both characters have similar types of jobs which do not require high educations to be one. Being both photographer and musician, the skill that is emphasized is on their physical ability, which is having a good gaze and pleasant voice. Not illustrating them having other occupations, the two jobs are chosen for them. It affirms to the stereotype that Black people do not have high education, and both occupations are related to jobs which are categorized to the Black race. That is, jobs require skill more than education. Black people have always been considered to have excellent singing skills, especially in the genre of Jazz. As Klitz (1989) has stated about the history of how Black people are the experts in Jazz music, he has written that Black people have been involved because, in the past, 
the profession is not full of White people. The musician Black character is Logan King or his real name is Andre Hayworth, who is known to be a Jazz musician from a scene when Rod looks up for him on the Internet (01:12:14). Photography is also considered as a job related to Black people as they are known to have good eye gaze, which is the reason the winner of the auction wants to own Chris' body. The two jobs focus more on skill than education.

The Armitages, main White characters, have the occupation of being intellectuals, such as doctor and psychologist. The choice of placing White characters to be the sophisticated ones is putting the Whites into the hierarchical stereotype in society. By being white and intelligent, based on the depictions, they have the power and freedom to do anything they want. The way the family of Armitages has the occupations of intellectuals: Dean Armitage as a neurosurgeon and Missy Armitage as a psychologist enforce the power of White people in the movie. On top of that, brain-transplantation surgery operated by Dean Armitage explains the advanced technology that White people can use, and hypnosis becomes a medium to show the capacity of White people through 'innovative machinery' (Schlereth, 1991).

The occupations of other White characters presented as the guests in the house of the Armitages for the auction party are not explained, but a White male character is explained. The only one White guest whose occupation is told is Jim Hudson, the blind White male character who almost gets Chris' body in the end. It is known from the dialogue between him and Chris (00:47:00) that he owns art galleries, Hudson galleries, and he eventually tells that he is an art dealer. It already shows the power relation in job division between the two races. Even though they have similar fields, both in the field of art, Chris is in a lower status than Jim Hudson. This labour division between the two characters shows that a Black character is represented having a lower status than a White character. It can also be a criticism towards the society that discrimination in the workplace is still found towards Black people as the majority of White people still think that Black people are unintelligent and prefer to live on welfare than work themselves. (Feagin et al., 2001 (as cited in Ferber (2007)).

\section{Distinctive Music to Show Oppression}

As this movie tries to depict distinctions between both races, White and Black, it also uses musical aspects, such as songs and lyrics in showing them. The general portrayal is shown using different types of music and lyrics in both races' scenes. The music and sounds played in White people scenes are different from the ones used in Black people's parts. The plot shows that those types of music are used to show the stereotypical images of the races as well as their emotional conditions in their everyday lives. Further explanations will be shown below.

To begin with, the movie provides hints about the plot with the use of music in several scenes. However, before knowing the ending, some people may interpret about Black people's relation with suspense and thrilling situation by the use of music as Black people are known to be dangerous. According to Brooks \& Hébert (2006), Martin and Yep have pointed out that Black masculinity in hip hop culture represents "anger, violence, and sexual aggressiveness" (p.307). This statement shows the relation between the use of music in Black people, especially hip hop, and violence.

One particular scene to show the issue is the first scene when an unknown Black man, later known as Logan King, walks around a White, middle-class neighbourhood. He feels scared as it is tranquil, but at the same time, the scene depicts an anti-mainstream situation where a Black man is in horror around the middle-class houses. His hunch is proven by him being kidnapped by an unidentified man coming in a white car. There is a long silence right before the kidnapping giving the suspense towards the situation. As the scene shows a car's door that is opened, the unidentified man is listening to an old song with upbeat music in the car. It acts as a contrast to the whole situation in the scene. Below are the lyrics shown in the scene:

"Run rabbit - run rabbit - Run! Run! Run! Don't give the farmer his fun! Fun! Fun! He'll get by

Without his rabbit pie 
So run rabbit - run rabbit - Run! Run! Run!"

(00:02:43-00:03:05)

The song title is "Run Rabbit Run" sung by two British comedy-singing duo, and it was very popular during World War II. (Ray, 2017). The song repeats some words several times. Repetition acts as a strategy used to emphasize and give emotional effect (Rhetoricae, 2006). The expression 'run rabbit', according to Ray (2017), historically refers to the alleged victims, two rabbits, in the crater after Germans did bombing. The phrase 'rabbit pie' refers to the way the rabbits will be made into a rabbit pie. This song acted as a mockery towards Germans, while it boosted British people's morale. The movie Get Out (2017) uses it as a hint about the danger the Black man is facing through race opposition. The scene implies that 'run' means 'avoid', while 'rabbit' refers to 'Logan King' in this case because a rabbit is usually used as an experimental object (Thomas, Bhat, \& Mapara, 2012) in operation, which is similar to Logan King in the movie. Being a weak being, compared to a rabbit, he is told to run away from White people. This phrase gives a warning towards Logan King to avoid the 'farmer'. Meanwhile, a rabbit pie is a pie made of rabbit meat. It signifies that Logan King should avoid the unidentified man before he becomes a 'rabbit pie' or goes into another form. The transformation in the movie refers that there are two souls in a Black person's body, White and Black people.

Moreover, after the song 'Run Rabbit Run' ends, a piece of country music is added. That is an African-American song titled "Sikiliza Kwa Wahenga" shows up. Moore (2017) describes that the song title was derived from a Swahili phrase meaning "listen to your ancestors". That is, 'Sikiliza' means 'listen', 'Kwa' means 'for', and 'Wahenga' means 'ancestor'. From the historical context, the music used in the scene relates the condition in the scene by referring it to the ancient time when White people turned Black people into slaves. The lyrics can be compared by putting both the Swahili version and English version side by side. The lyrics are taken from Genius.com (n.d.) (Swahili version), Gayo (2017) (English version), and some additions from Google Translate. Look at table 1.

According to the lyrics, the song says that the audience should listen to their ancestors and their hearts. They are told to run away from the danger they will face. The word 'brother' shows that they consider one another as a family or as brothers. The song seems to be given by fellow Black people to the listener, which is Chris in this case, asking to run away. The song Sikiliza Kwa Wahenga and Run Rabbit Run have aligned meaning and warning towards the listeners. It is to run from the danger they will face. Both songs are played in the scenes of Chris and Logan King, who are Black people. The songs hint about the situation they will meet.

Table 1. Swahili and English versions of 'Sikiliza Kwa Wahenga' lyrics

Sikiliza Kwa Wahenga (Swahili Version)

Brother

Sikiliza kwa wahenga

Brother

Sikiliza, sikiliza, sikiliza kwa wahenga

Kimbia, unakimbia mbali

Sikiliza, sikiliza, sikiliza kwa wa'

Brother, sikiliza, sikiliza, brother, sikiliza, sikiliza

kwa wahenga, brother

Kimbia, sikiliza, sikiliza, kimbia, sikiliza, sikiliza

kwa wahenga, kimbia, sikiliza

Kuokoa mwenyewe, ooo-ooooh

Sikiliza, sikiliza, sikiliza kwa wahenga

Kuokoa mwenyewe, ooo-ooooh

Sikiliza... kwa wahenga
Sikiliza Kwa Wahenga (English Version)

\section{Brother}

Listen to the ancestors

Brother

Listen, listen, listen to the ancestors

Run, you run away

Listen, listen, listen to '

Brother, listen, listen, brother, listen,

listen to the ancestors, brother

Run, listen, listen, run, listen,

listen to ancestors, run, listen

Save yourself, ooo-ooooh

Listen, listen, listen to the ancestors

Save yourself, ooo-ooooh

Listen ... for sages 
Running away means that the one who runs away is weaker than the chaser. As Black people become the ones who run away, it shows that they are weaker than White people. In other words, they are inferior to White people. Using Sikiliza Kwa Wahenga, they are reminded of their historical memory of being White people's slaves.

There is a scene showing hint about the driver of a white car in the kidnapping scene of Logan King. Before the surgery, Chris asks, "Where is Rose?" (01:22:35), and Jim answers by saying, "Oh, you dirty dog. You're one of the lucky ones, trust me. Jeremy's wrangling method sounds way less pleasant." (01:22:37 - 01:22:45). The dialogue shows that Jeremy uses 'wrangling' method as also shown in the scene of Chris running away from the house, Jeremy is seen using violence to get Chris. This 'wrangling' method seems to refer to animal wrangling. Going back to the first scene, Logan King, or Andre Hayworth, is seen taken by an unidentified man in a white car. Using the hint, it is assumed that the kidnapper is Jeremy, and the use of a white car symbolizes a White person who drives it. Based on the aspects discussed above, the use of the White car as a vehicle used to approach Logan King in the scene seems to represent the act that White people also did in the past. The hints and songs are put into those scenes because they focus on dangers happening to Black people. The songs used in the film have a deeper purpose for the movie's goal, and it is also supported by using a white car which seems to symbolize White people.

The sound aspect of the garden party scene implies the message and shows the ambience of the conversation. There are many sounds heard in the scene. One of them is the human voices in a conversation between Chris and Rose with other White families whose contents have been explained in the subheading of Black Masculinity. The other two sounds are the musical score and the water sound being the main points here. The musical score is used thrice in the Garden party scene $(00: 43: 06,00: 43: 33$, and 00:43:58). The sound comes from a piano. The notes go up and down rapidly depicting questions in Chris' mind when talking to the White families. It is inserted to give the audience a signal of where to focus on and emphasize the contents of the conversation. It can be categorized as a mysterious sound due to its purpose in the scene. As for the sound of water, it is applied continuously throughout the scene as there is a water fountain near them but at the same time acts as a symbol within it. Water is associated with purity as "an image of the soul" (p.64) (Latiff, Yunus, \& Mydin, 2016). As this conversation involves White people and a Black man, the sound of water implies the image of the group of White people as pure and calm. The water acts as a White people's cover so that Chris does not catch their intention. However, the addition of the sound effect after the White guests share their opinions about Chris, who gives an ironic signal about the real danger that is about to happen. By using these sounds, White guests seem to be putting Chris under control.

Not only that part, but other parts of the movie also have a depiction of the oppression of Black people by White people. The oppression of White people towards Black people is illustrated with brain surgery or called as a coagula operation. Here, the difference in the musical aspect is noticeable by depending on the possession of the power. When the scene shows White people attempting to acquire the Black man's body through the surgery, the music used is vibrant with instruments. The sounds heard are from strings, and a bit of percussion. The music sounds majestic as there is a combination sound between a choir group and an orchestra. As the beats are not too fast or too slow, the music becomes grand and dramatic. It ends with two hits of the bass drum as an emphasis on the intense situation. As Chris becomes aware of the situation, the song Sikiliza Kwa Wahenga comes out again but with the dramatic sounds of drums. It shows that Chris is unstable emotionally at the time. Meanwhile, Dean Armitage, who tries to do brain surgery towards Jim Hudson and Chris Washington is seen to be calm emotionally even though he is doing something hazardous. Being oppressed, the movie portrays Chris being attached to his chair, while Jim Hudson, the White counterpart, is free without being attached. The different action shows degrading attitude towards Black people. 
The scenes discussed above illustrate similar conditions of their racial stereotype in the society today with the era when White people colonized black people. As a result, the use of music mainly depicts White people as calm and influential throughout the situation by the use of country music, while it shows Black people's fear of their surroundings by the use of music which is full of beats. Still being oppressed in current society, the Black characters are as anxious in their everyday lives as they were in the past. Using historically related songs, which are Run Rabbit Run and Sikiliza Kwa Wahenga, the movie crews can portray distinctive emotions from both sides.

\section{Conclusion}

To summarize the paper, it is still seen that Black characters are portrayed based on the stereotypes that are widely spread in the U. S. society through popular cultures like movies, TV-series, and news. Black people are still seen inferior compared to other races, especially White people, as their historical opposition. Being minorities, the creation of accessible media is also hard to be controlled. Several movies have tried to reinforce the positivity of Black people's traits, some are successful, and some are not. In this analysis of the movie Get Out (2017), which tries to reinforce Black people, there are some stereotypical depictions left for the Black characters. The stereotypical aspects which are found in this finding, firstly, involve Black masculinity, which highlights more on Black people's body rather than on their mind. It is seen that the Black masculinity aspect in the movie is portrayed as a boundary between fear and admiration. Secondly, they seem to be lacking in civility aspect compared to their White counterparts, showing the way Black people go through their daily life having inappropriate behaviour. This depiction becomes problematic as it puts the characteristics into any Black characters. Thirdly, there is a distinctive labour division between Black and White characters, including only some portions related to physical trait rather than intelligence for Black people. Black characters here always seem to be perceived as more athletic than intelligent, so they get the occupations that are more related to athletic, such as a TSA agent and police officers, or even do not require high education, such as photography and musician. Nevertheless, the movie has successfully used music to support different depictions of Black and White people. The movie uses suspense music for Black people, whereas relaxing music for White people. At first, it may seem that it follows stereotypical depictions of Black people with the use of thrilling music and all, but the ending explains it all.

Some hints are not visible on the surface because the movie intends to highlight Black people as protagonists. The movie production aims to enhance Black people's position by their representation in popular culture. However, if the scenes are dug deeper, it still has some weaknesses in depicting them. This movie is very rich in aspects and symbols other than about the representation aspect, so sometimes it is hard to differentiate one meaning to another. Being able to put Black characters as the heroes in this movie does not guarantee that the movie is able to uncover the stereotypes of Black characters in the portrayal ultimately. As this representation issue still revolves around the World until today, this paper is expected to provide more perspectives on the fact that the way Black people are still seen inferior in the movie. Many movies have still depicted Black characters as the stereotypes that are spread in the society. The upcoming movies which empower Black people are expected to give Black people the attitudes they deserve to get.

\section{References}

Adams, T. L. (2015). An ideological Criticism of Portrayals of Black Men in Film: an Analysis of Drumline, Dangerous Minds, Higher Learning, and Stomp the Yard. (The University of Akron; Vol. 13). Retrieved from https://etd.ohiolink. edu/

Brooks, D. E., \& Hébert, L. P. (2006). Gender, Race, and Media Representation. The SAGE Handbook of Gender and Communication, 297-318. https://doi.org/10.4135/9781412976053. n16 
Clark, C. M. (2008). Civility: A concept analysis. (January 2008).

Collins, P. H. (2004). Black Sexual Politics: African Americans, Gender, and the New Racism. New York \& London: Routledge.

Ferber, A. L. (2007). The Construction of Black Masculinity: White Supremacy Now and Then. Journal of Sport and Social Issues, 31(1), 11-24. Retrieved from http://ejournals.ebsco. $\mathrm{com} /$ direct.asp?ArticleID=4A44ACAD0DE8 FC6A7129

Fletcher, J. (2013). Deer as Symbols. In Deer (pp. 117-144). Retrieved from https://search. proquest.com

Gayo, L. (2017). Sikiliza - There is More to the Swahili Song in "Get Out." Retrieved from https://medium.com/@loycegayo/sikilizathere-is-more-to-the-swahili-song-in-get-out79ebb1456116

Genius.com. (n.d.). Michael Abels - Sikiliza Kwa Wahenga (Main Title) Lyrics. Retrieved from https://genius.com/Michael-abels-sikilizakwa-wahenga-main-title-lyrics

Hazelton, J. (2017). "Get Out": Review. Retrieved October 2, 2018, from https://www.screendaily.com/reviews/get-out-review/5115376. article

Henry, K. L. (2017). A Review of Get Out: On White Terror and the Black Body. Equity and Excellence in Education, 50(3), 333-335. https://doi.org/10.1080/10665684.2017.13 36952

Hertz, C. (2007). The Uniform: As Material, As Symbol, As Negotiated Object. Midwestern Folklore, 43-58. Retrieved from https://www. academia.edu/4044048/The_Uniform_As_ Material_As_Symbol_As_Negotiated_Object

Kavari, R. (2018). Loss for Identity and Racial Melancholy in Nadine Gordimer's Burger's Daoughter and Zakes Mda's the Madonna of Exelstor (The University of Namibia). Retrieved from http://repository.unam.na/ bitstream/handle/11070/2322/kavari2018. pdf?sequence $=1$ \&isAllowed $=y$.

Klitz, B. (1989). Blacks and Pre-Jazz Instrumental Music in America. International Review of the
Aesthetics and Sociology of Music, 20(1), 43. https://doi.org/10.2307/836550

Landsberg, A. (2018). Horror vérité: politics and history in Jordan Peele's Get Out (2017). Continuum, 32(5), 629-642. https://doi.or g/10.1080/10304312.2018.1500522

Lathan, J. (2016). Community Schools, Empowermenty, Systems Thinking, and Race: A Model for Change. (Mills College). Retrieved from https://remote-lib.ui.ac.id:2155/docview/185 0507656 ? accountid $=17242$.

Latiff, Z. A., Yunus, Y. M., \& Mydin, M. A. O. (2016). Symbolism and Role of Water in Traditional Islamic Gardens. 11(3), 62-68.

Moore, C. P. (2017). The hidden Swahili message in "Get Out" the country needs to hear. Retrieved March 29, 2019, from https://splinternews. com/the-hidden-swahili-message-in-get-outthe-country-needs-1793858917

Peele, J. (Director). (2017). Get Out[Video file]. USA.

Ray, D. (2017). "Run Rabbit Run" by Flanagan and Allen - ENG 410: WWII Literature. Retrieved from https://eng410wwiilit. commons.gc.cuny.edu/2017/11/27/runrabbit-run-by-flanagan-and-allen/

Rhetoricae, S. (2006). figures of repetition. Retrieved April 2, 2019, from http://rhetoric. byu.edu/Figures/Groupings/ofRepetition.htm

Schlereth, T. J. (1991). Victorian America: transformations in everyday life, 1876-1915 (R. Balkin, Ed.). Harper Collins.

Ştefanovici, S. (2014). Black Stereotypes in American Movies. 70-76

Thomas, B., Bhat, K., \& Mapara, M. (2012). Rabbit as an animal model for experimental research. Dental Research Journal, 9(1), 111. https://doi.org/10.4103/1735-3327.92960

Weaver, T. (2016). Analysis of Representations of African Americans in Non-linear Streaming Media Content. 7(2), 57-67.

Williams, M. E. (2017). A horror movie for our time: "Get Out" is frighteningly topical. Retrieved October 17, 2018, from https:// www.salon.com/2017/02/24/a-horror-moviefor-our-time-get-out-is-frighteningly-topical/ 